\title{
CHAPTER E: GEOCHEMISTRY OF THE IGNEOUS ROCKS IN THE LADUE RIVER-MOUNT FAIRPLAY AREA
}

\author{
Alicja Wypych ${ }^{1}$
}

\section{INTRODUCTION}

During the 2019 summer field season, geologists from the Alaska Division of Geological \& Geophysical Surveys (DGGS) carried out a geologic mapping and geochemical sampling project in the Ladue River-Mount Fairplay map area. We generated modern geochemical data for 408 samples (Wypych and others, 2019), and to support map interpretations, we analyzed 1,685 cut surfaces of hand samples using a handheld X-ray fluorescence (XRF) analyzer calibrated to mafic-to-silicious rock standards. We split igneous rocks into six major groups based on crystallization age, geochemical composition, and textural characteristics: 1) Paleocene to Eocene rhyolite and felsic porphyry; 2) Late Cretaceous volcanic rocks; 3) Late Cretaceous intrusive rocks; 4) Late Cretaceous units of the Mount Fairplay intrusive complex in the northwestern part of the area; 5) mid-Cretaceous volcanic rocks and dikes of McArthur Creek area in the southern tip of the area; and, 6) mid-Cretaceous intrusive and extrusive rocks (fig. 1). The Mount Fairplay complex has been studied in greater detail by Newberry (2020). All units are shown on the total alkali $\left(\mathrm{Na}_{2} \mathrm{O}+\mathrm{K}_{2} \mathrm{O}\right)$ versus silica $\left(\mathrm{SiO}_{2}\right)$ diagram (TAS) for intrusive and volcanic rocks (figs. $2 \mathrm{~A}$ and $\mathrm{B}$ ). The plutonic rocks exhibit a range of mafic to felsic compositions. Similarly, the volcanic rocks have a broad compositional range from mafic to silicic ( $\mathrm{SiO}_{2}$ from 53 to 79 weight percent). A supplemental spreadsheet that relates map units to samples from the geochemical report used for this interpretation can be downloaded from https:// doi.org/10.14509/30739. See Wypych and others (2019; https://dggs.alaska.gov/pubs/id/30267) for full documentation of the sample collection, preparation, and analytical methods.

\section{GEOLOGIC BACKGROUND}

Previous geologic investigations in the eastern Yukon-Tanana Upland region document periods of Triassic to Paleocene igneous activity (Foster, 1970, 1967; Werdon and others, 2001; Szumigala and others, 2002; Dusel-Bacon and others, 2015). Foster (1970) describes felsic lavas, tuffs, tuff breccias, pumice-breccias, volcanic conglomerates, and tuffaceous sediments, as well as mafic lavas, breccias, and tuffs in the region, and assigned them a probable Tertiary age based on pollen fossils found in interbedded sedimentary units, later revised to Cretaceous (Foster and others, 1994). Along with the Tertiary volcanic rocks, Foster (1970) describes equigranular to porphyritic diorite to granite intrusions of Mesozoic age. Due to its associated mineral potential, Mesozoic to Paleogene igneous activity has been further explored. Joyce (2002) investigated the mid-Cretaceous intrusions of the Moosehorn Range, Yukon, immediately adjacent to our map area, where she differentiated granodiorite, felsic and mafic porphyritic dikes, and granites, aplites, and pegmatites using multiple dating systems, geochemical composition, and detailed fieldwork. Extensive and voluminous mid-Cretaceous felsic volcanic rocks in the map area prompted Bacon and others (1990) to interpret these rocks as intra-caldera and near-caldera deposits and propose possible caldera locations. Late Cretaceous igneous activity immediately north of the map area at the Taurus porphyry prospect has been investigated in detail by Lerich (1995), Harrington (2010), Kreiner and others (2019), and the DGGS Mineral Resources section (Wypych and others, 2021; Twelker and Newberry, 2021). DGGS investigations include geochemical and age characterization of the Taurus granodiorite and quartz-feldspar porphyry, the Pika

${ }^{1}$ Alaska Division of Geological \& Geophysical Surveys, 3354 College Rd., Fairbanks, Alaska 99709-3707 


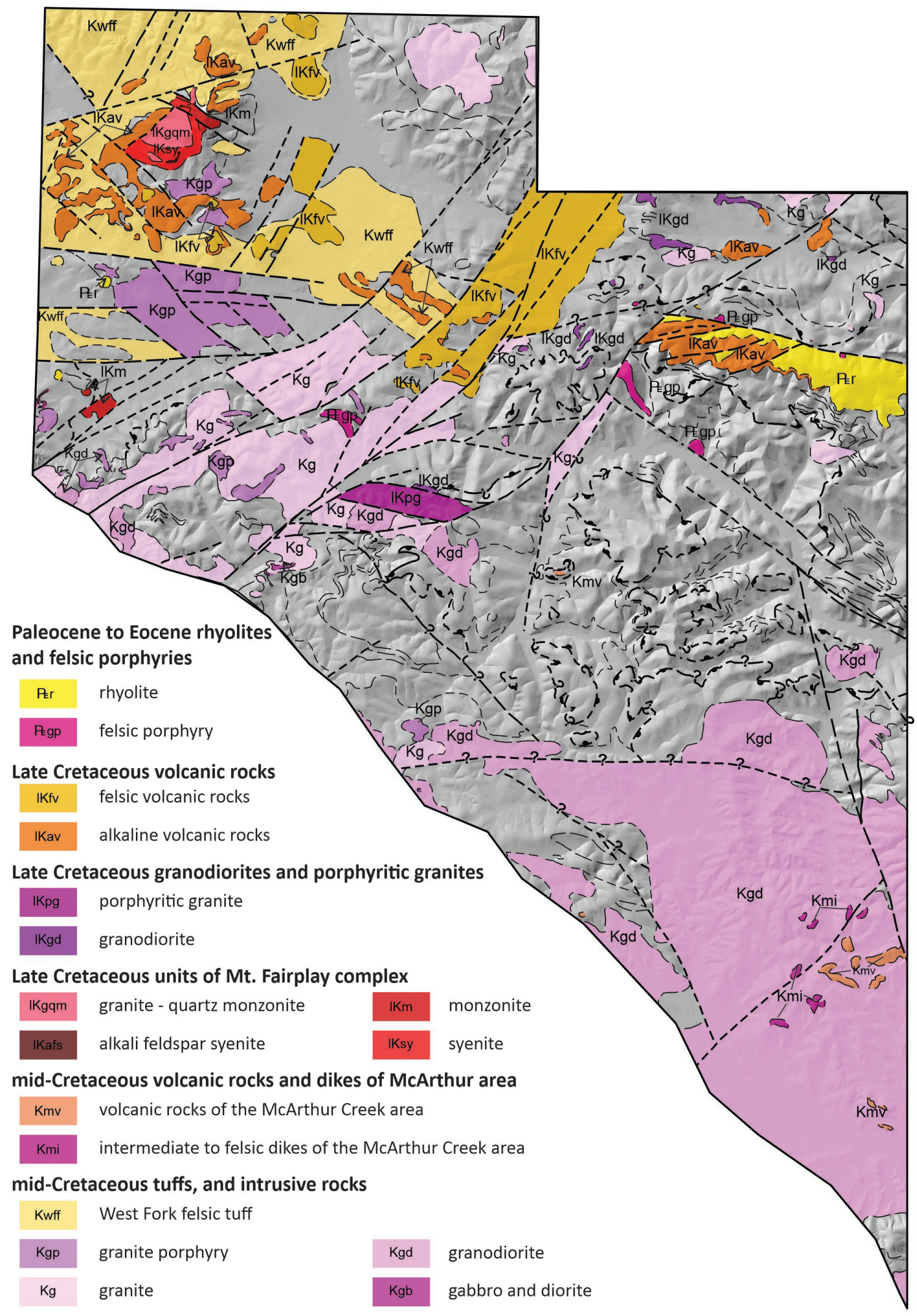

Figure 1. Geographic distribution of igneous units in the Ladue River-Mount Fairplay area (Twelker and others, 2021, sheet 1). Thin dotted, dashed, and continuous fine lines signify unit contacts; thicker dotted, dashed, and continuous lines represent faults. 

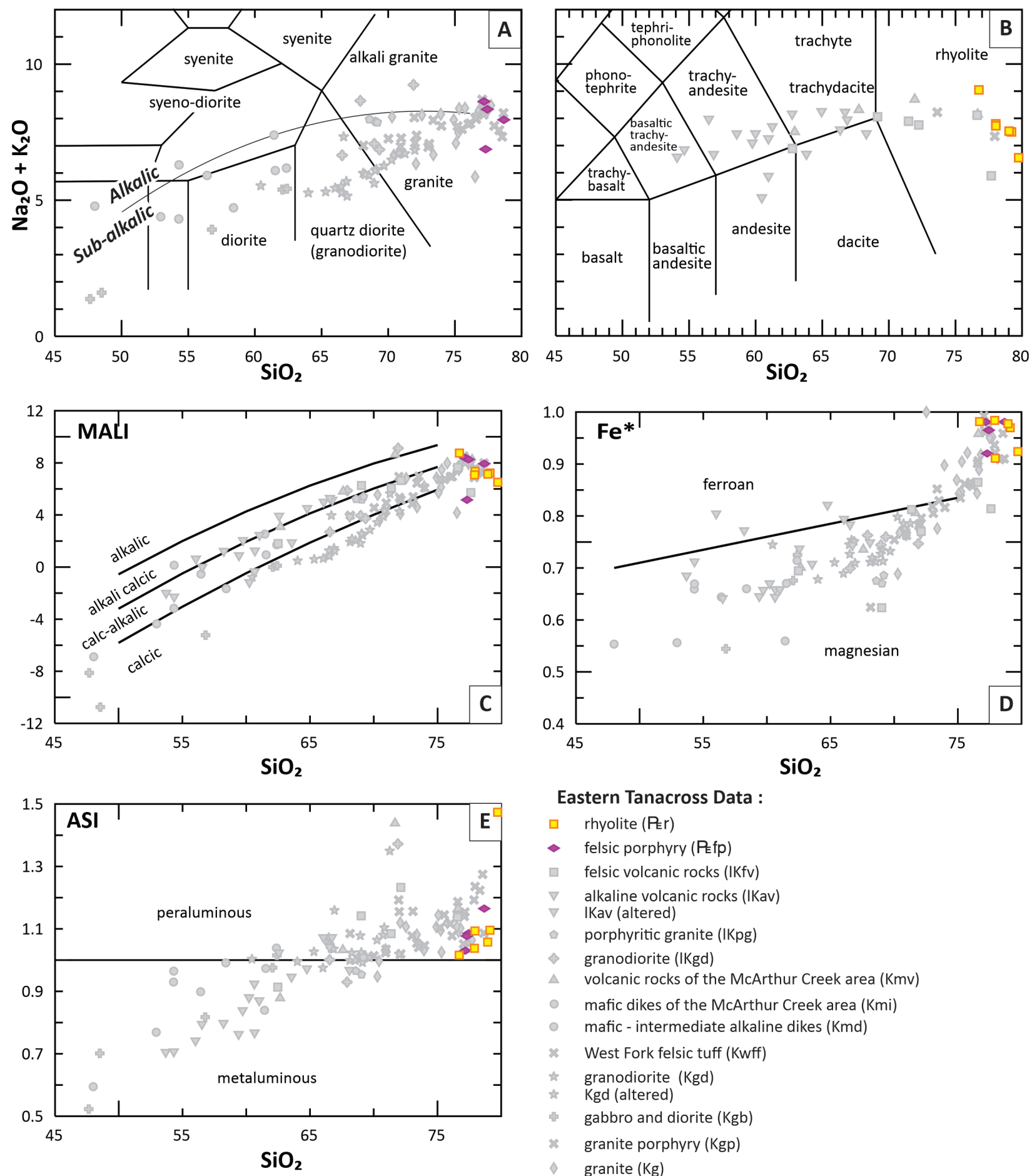

\section{Eastern Tanacross Data :}

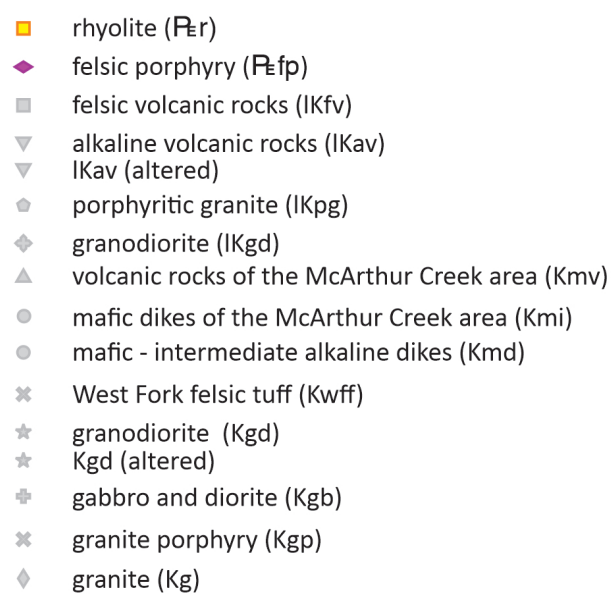

Figure 2. Classification diagrams for Paleogene igneous rocks from the Ladue River-Mount Fairplay area. A. Total alkali versus silica diagram with fields (TAS, labeled after Wilson, 1989) showing the compositional range of the plutonic rocks. B. TAS with fields (after LeBas and others, 1986) showing the compositional range of the volcanic rocks and dikes. C. Modified alkali-lime index (MALI $=\mathrm{Na}_{2} \mathrm{O}+\mathrm{K}_{2} \mathrm{O}-\mathrm{CaO}$; Frost and others, 2001). D. $\mathrm{Fe}^{*}=\left(\mathrm{FeO}_{\mathrm{tot}}\right) /\left(\mathrm{FeO}_{\mathrm{tot}}+\mathrm{MgO}\right) ;$ Frost and others, 2001). E. Aluminum saturation index diagram (ASI = Al / (Ca-1.67P+Na+K); Frost and others, 2001). Oxide data have been normalized to 100-percent anhydrous. 
diorite, and other volcanic rocks (Wypych and others, 2021). The Paleogene felsic igneous rocks are part of a bimodal, extension-related igneous province mapped in the region (for example, Newberry and others, 1996; Werdon and others, 2001). Here, we build on the findings of previous researchers and provide modern, whole-rock geochemical data for the samples in the map area, as well as regional comparisons and tectonic interpretations.

\section{PALEOGENE RHYOLITE AND FELSIC PORPHYRY}

The youngest igneous rocks in the map area are felsic porphyries ( $\mathrm{P} f \mathrm{fp}$ ) and related rhyolites (PEr). The porphyries are mainly present as small plugs and dikes concentrated in the central map area (Twelker and others, 2021), whereas the rhyolite unit consists of rhyolite and felsic tuffs outcropping in a single volcanic field north of Ladue River. The Paleogene units are highly siliceous, with $\mathrm{SiO}_{2}$ greater than 76 weight percent (fig. 2B), and are calc-alkalic to calcic, ferroan, and peraluminous (figs. 2C-E). The trace-element composition of the Paleogene units is distinctive and easily differentiated from older igneous rocks in the region (figs. $3 \mathrm{~A}-\mathrm{F}$ ). With the exception of one outlier with over 600 parts per million (ppm) strontium (Sr) and $300 \mathrm{ppm}$ barium (Ba), the units have low $\mathrm{Sr}$ concentrations (averaging $20 \mathrm{ppm}$, fig. 3A), low europium (Eu, 0.04 to 0.25 ppm, fig. 3D), and low $\mathrm{Ba}$ (15 to $85 \mathrm{ppm}$ ); all of these indicate fractionation of plagioclase and are characteristic of highly evolved magmas. The high field-strength elements (HFSE) are elevated, with thorium (Th) up to 40.7 ppm, yttrium (Y) averaging around $40 \mathrm{ppm}$ and up to $103 \mathrm{ppm}$, and zirconium $(\mathrm{Zr})$ averaging around 200 ppm (figs. 3C, E, and F). Likewise, heavy rare earth elements (REE) are elevated: ytterbium $(\mathrm{Yb})$ reaches near $10 \mathrm{ppm}$, lutetium $(\mathrm{Lu})$ over 1.3 ppm, and hafnium (Hf) nearing 10 ppm, whereas light REE are comparable to other units in the region (fig. 3B). All these trace-element characteristics indicate an extension-related magma source, which is further highlighted by niobium $(\mathrm{Nb})$ plus $\mathrm{Y}$ versus rubidium $(\mathrm{Rb})$ concentrations plotting in the within-plate granitoids field of Pearce and others (1984; fig. 4A). The high Y concentration was easily detectible using a handheld XRF analyzer in the field office, thus allowing immediate recognition of the unit. Figures 3A, 3C, 3E, and 3F illustrate the handheld XRF data in comparison to the ICP-MS-derived trace-element geochemical data.

\section{LATE CRETACEOUS IGNEOUS ROCKS}

Late Cretaceous igneous rocks in the map area are grouped into: volcanic rocks (felsic [IKfv] and alkaline [IKav]); granodiorite to granite (IKgd) and porphyritic granite (IKpg); and, intrusive rocks of Mount Fairplay complex (granite-quartz monzonite [IKgqm]; alkali-feldspar syenite [IKafs]; monzonite $[\mathrm{IKm}]$; and, syenite [IKsy]).

Felsic volcanic rocks are concentrated along the East Fork of the Dennison Fork of the Fortymile river and include felsic tuffs, dacites, and rhyolites. The porphyritic granite is a fault-bound unit located west of the Oreo Mountain porphyry copper-molybdenum prospect in the Tanacross B-2 Quadrangle, $13 \mathrm{~km}$ east of Ladue River, and is characterized by large potassium feldspar phenocrysts in a medium-grained groundmass consisting of quartz, feldspar, hornblende, and biotite. Unit IKgd dikes and stocks outcrop in the area between the Taurus and Oreo prospects and can be compared compositionally to quartz-feldspar porphyry (Kqp), Taurus granodiorite (Ktgd), and Pika diorite $(\mathrm{Kpd})$ in the Northeast Tanacross geologic map area (figs. 4B-6, Wypych and others, 2021). The Late Cretaceous felsic rocks exhibit high $\mathrm{SiO}_{2}$ concentrations, from 66.0 to 77.6 weight percent, with one exception of 62.5 weight percent (figs. 5A and B). They are calc-alkalic, magnesian, and largely metaluminous (figs. 5C-E), except for the peraluminous volcanic rocks (IKfv) (fig. 5E). Unit IKfv is highly siliceous; we have observed only a couple of such high-silica rhyolites in the Northeast Tanacross map area and there we assigned them to volcanic rocks unit $\mathrm{Kv}$ (Wypych and others, 2021). The trace-element composition of IKfv generally overlaps that of the 
other felsic samples (figs. 6A-F) and is comparable to that of the most siliceous Kv samples (Wypych, 2021). Late Cretaceous porphyritic granite (IKpg) is characterized by its elevated magnesian character compared to other igneous rocks of similar silica composition in the map area (fig. 5D). Similar to IKav, unit IKpg has trace-element characteristics similar to Kv from the Northeast Tanacross

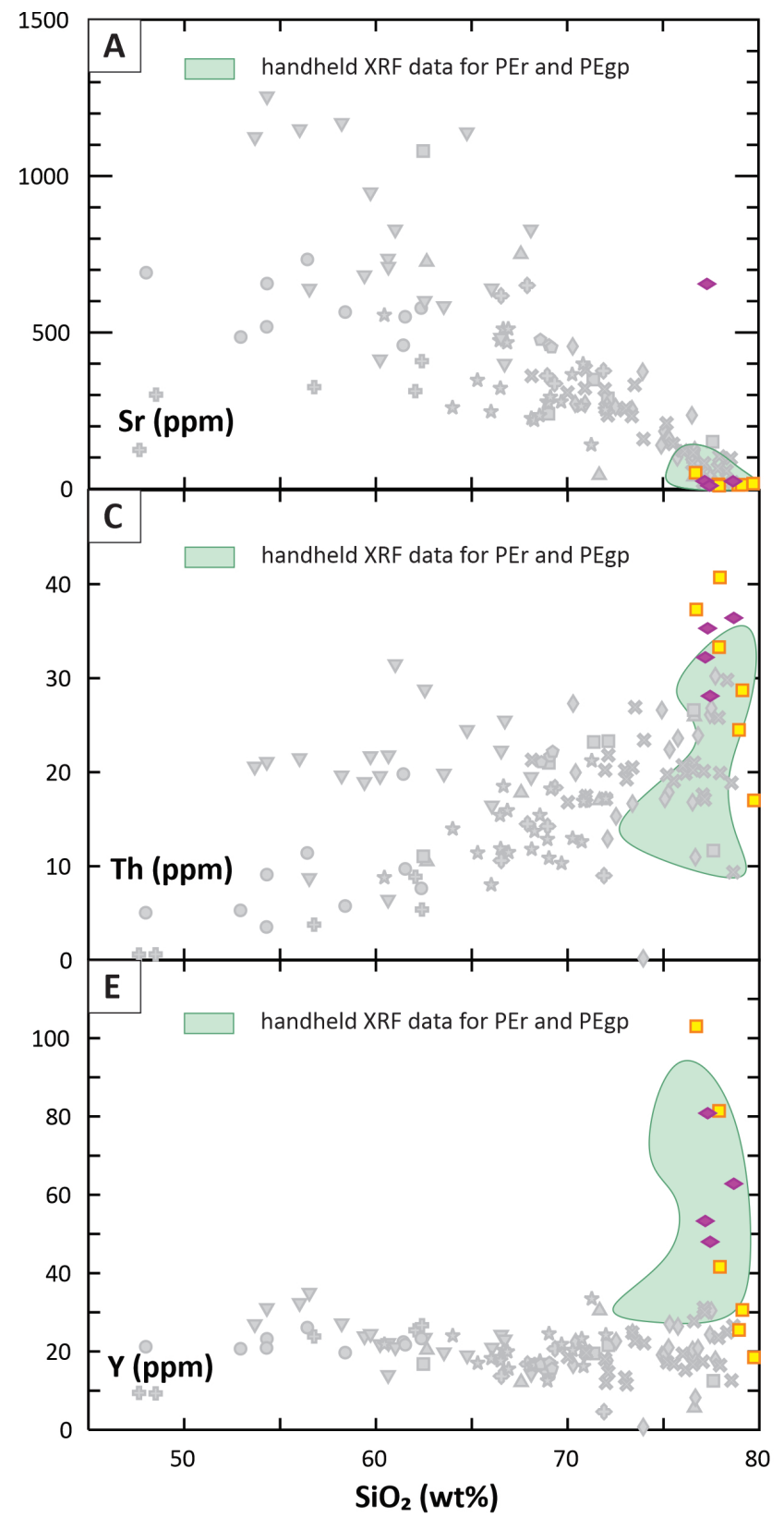

map area (figs. 6A-F). In terms of major-element composition, unit IKgd follows the Ktgd unit of the Northeast Tanacross map area (Wypych, 2021). However, the trace element composition of unit IKgd suggests a better correlation to the Pika diorite (Kpd) unit in the Northeast Tanacross map area (figs. 6A-F). This unit has lower lanthanum (La), Th, and Eu than most Ktgd (figs. 6B-D), and lower

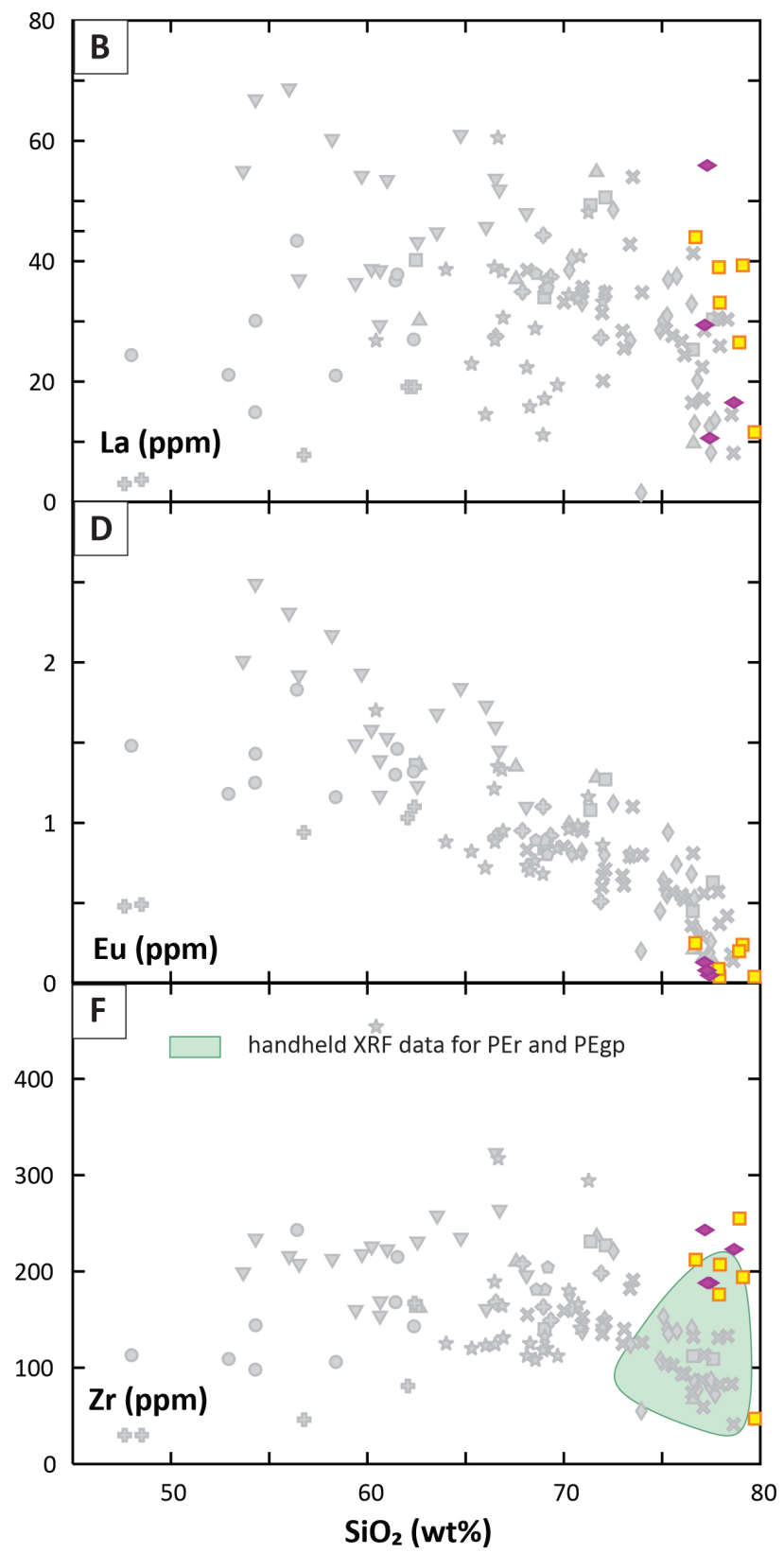

Figure 3. Bivariate plots of $\mathrm{SiO}_{2}$ (wt.\%) vs. selected trace element abundances (ppm). Symbols and colors as in figure 2, pale green polygons represent major- and trace-element data collected using hand-held XRF for Paleogene rocks. 

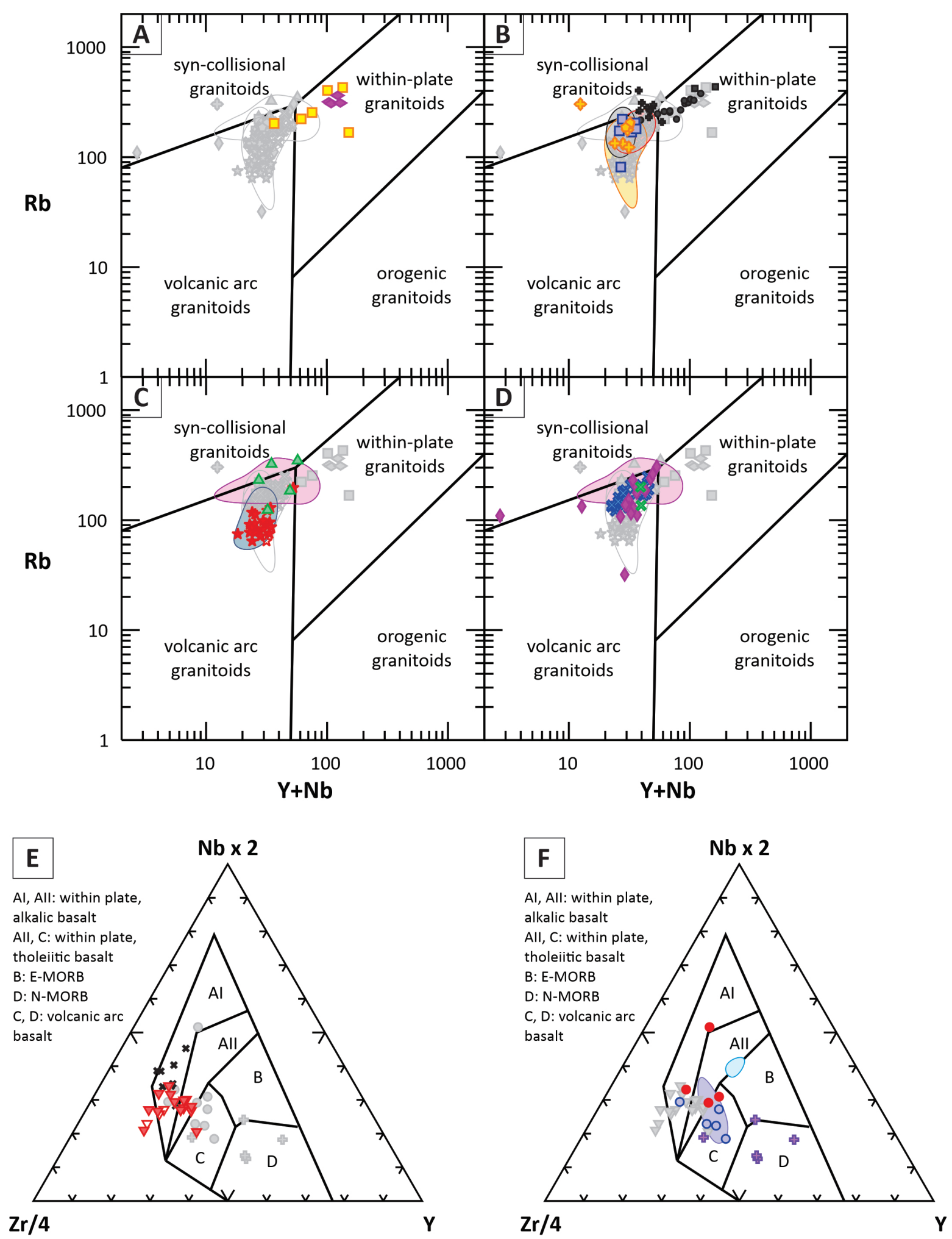

Figure 4. Tectonic classification diagrams for felsic igneous rocks from the Ladue River-Mount Fairplay area after Pearce and others (1984) for: (A) Paleogene rocks; (B) Late Cretaceous granitoids; (C) mid-Cretaceous volcanic rocks of McArthur Creek area (Kmv) area and granodiorite (Kgd); and (D) mid-Cretaceous West Fork felsic tuff (Kwff), granite porphyry (Kgp) and granite $(\mathrm{Kg})$; (E) high field-strength element, tectonic discrimination ternary diagram for Late Cretaceous mafic rocks (after Meschede, 1986); and (F) high field-strength element, tectonic discrimination ternary diagram for mid-Cretaceous mafic rocks (after Meschede, 1986). 

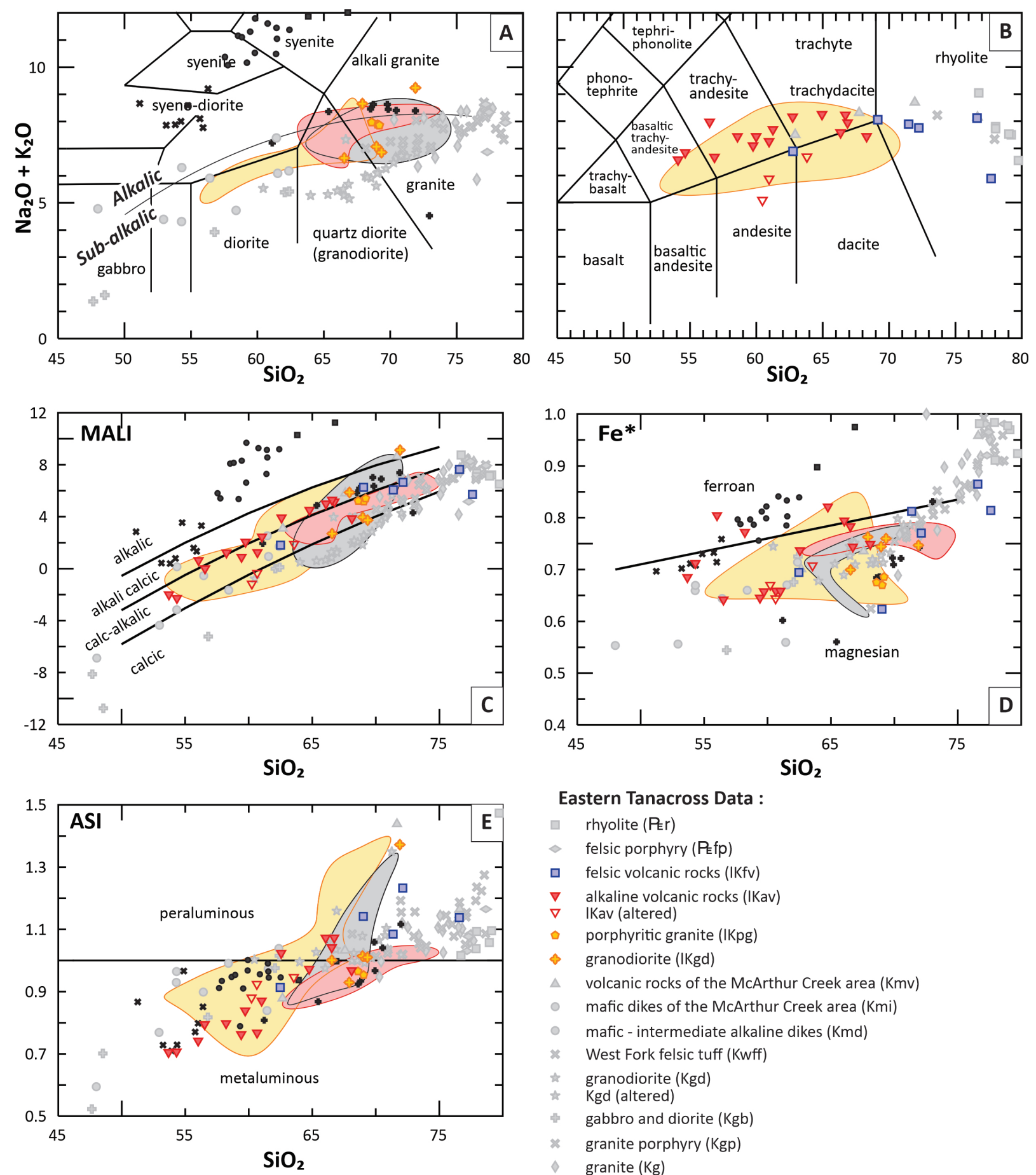

Eastern Tanacross Data :

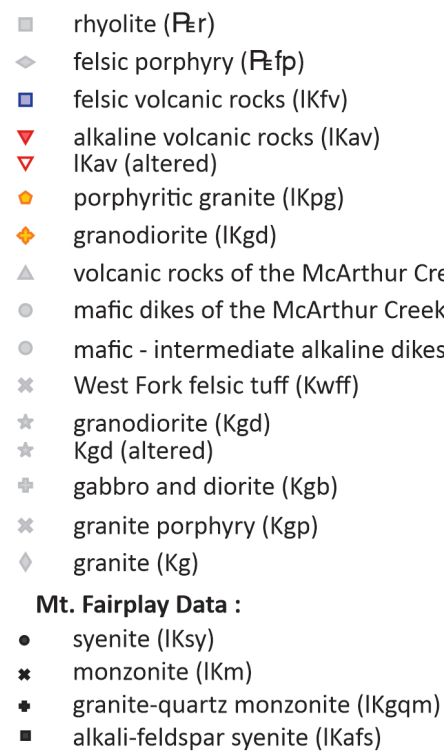

Figure 5. Classification diagrams for Late Cretaceous igneous rocks from the Ladue River-Mount Fairplay area. A. TAS showing the compositional range of the plutonic rocks. B. TAS showing the compositional range of the volcanic rocks and dikes. C. $\mathrm{MALI}=\mathrm{Na}_{2} \mathrm{O}+\mathrm{K}_{2} \mathrm{O}-\mathrm{CaO}$; Frost and others (2001). D. $\mathrm{Fe}^{* *}=\left(\mathrm{FeO}_{\text {tot }}\right) /\left(\mathrm{FeO}_{\mathrm{tot}}+\mathrm{MgO}\right) ;$ Frost and others (2001). E. ASI $\mathrm{ASI}=\mathrm{Al} /(\mathrm{Ca}-1.67 \mathrm{P}+\mathrm{Na}+\mathrm{K})$; Frost and others (2001). Oxide data have been normalized to 100-percent anhydrous. Open symbols signify samples described (in the field by the collector) as "altered;" closed symbols represent samples described as "unaltered" or "fresh." 
Sr than Kqp (fig. 6A). All the above late Cretaceous intrusive units, as well as the felsic volcanic rocks, have $\mathrm{Nb}$ plus $\mathrm{Y}$ and $\mathrm{Rb}$ concentrations characteristic of volcanic-arc granitoids (fig. 4B).

Alkaline volcanic rocks (IKav) are basaltic trachyandesite to trachydacite lava flows and tuffs, with $\mathrm{SiO}_{2}$ composition between 51 and 66 weight percent, and total alkali between 5 and 8 weight percent. This group is mainly alkali-calcic, magnesian, and metaluminous, however, a few samples display calc-alkalic, ferroan, and peraluminous compositions (figs. 5B-E). This group generally follows major element composition of the volcanic rocks observed in the Northeast Tanacross map area (Kv, figs. 5B-F) but trace elements are distinct. The elevated La, Th, and Zr (figs. 6B, C, and F) distinguishes this unit from any Late Cretaceous unit mapped in the Ladue River-Mount Fairplay map area. This unit is unique as it clearly has within-plate tectonic affiliation, as highlighted on the $\mathrm{Zr}-\mathrm{Y}-\mathrm{Nb}$ classification triangle for mafic rocks (fig. 4E).

The units of Mount Fairplay complex outcrop about $85 \mathrm{~km}$ north from Alaska Highway junction along the Taylor Highway, and are often porphyritic, with large feldspar phenocrysts in a mediumto-coarse-grained matrix. They are largely mafic, ranging from 50 to 67 weight percent $\mathrm{SiO}_{2}$, with the exception of granite-quartz monzonite (unit IKgqm), which has 69 to 76 weight percent $\mathrm{SiO}_{2}$, and generally forms a different trend than the rest of complex, resembling more closely other Late Cretaceous units of the region (figs. 5A-E). Granite-quartz monzonite and part of monzonite (IKm) unit are alkali-calcic and magnesian, whereas the syenite and alkali-feldspar syenite (IKsy and IKafs) are strongly alkalic and ferroan (figs. 5C and D), all the Mount Fairplay units are metaluminous, except for a few samples from the granite-quartz monzonite (fig. 5E). The high-alkali units also have distinctive trace element patterns from all other igneous units, particularly visible in the $\mathrm{Sr}, \mathrm{La}, \mathrm{Th}$, and $\mathrm{Zr}$ concentrations (figs. 6A-C and F). Those elements are elevated in the units, with $\mathrm{Sr}$ reaching $1,655 \mathrm{ppm}, 261 \mathrm{ppm}$ of Th, and 1,030 ppm of
Zr (figs. 6A, C, and F; Wypych and others, 2019). The granite-quartz monzonite, on the other hand, follow the late Cretaceous unit trends (figs. 6A-E) apart from slightly elevated $\mathrm{Zr}$ (fig. 6F). The syenites are characterized by largely within-plate chemical composition, and the granite-quartz monzonite is of volcanic-arc with some syn-collisional affinity samples present (figs. 4B and E).

\section{MID-CRETACEOUS IGNEOUS ROCKS}

The mid-Cretaceous igneous rocks in the Eastern Tanacross geologic map area are extensive and include volcanic rocks and dikes of the McArthur Creek area (Kmv and $\mathrm{Kmi})$, mafic to intermediate alkaline dikes (Kmd), the West Fork Tuff (Kwff), granodiorite and gabbro and diorite (Kgd and $\mathrm{Kgb}$ ), and granite porphyry and granite (Kgp and $\mathrm{Kg}$, fig. 1). The units observed in the map area are much more diverse in terms of textures, ages, and geochemical composition than the mid-Cretaceous rocks observed in our Northeast Tanacross map area (Kg; Wypych and others, 2021) and range between 45 and 78 weight percent $\mathrm{SiO}_{2}$ (figs. 7A and B). Like $\mathrm{Kmi}$, the alkaline dikes (Kmd) intrude the large granodiorite (Kgd) batholith in the southern quadrant of the map area. Rhyolite to dacite West Fork tuffs and flows (Kwff) cover a very large area in the northwest quadrant of the map area, and granite porphyry (Kgp) and granite $(\mathrm{Kg})$ are mainly observed just south of Kwff. Because of extensive weathering and alteration in the tuffaceous Kwff unit, only two fresh samples were available to analyze by commercial lab whole-rock methods.

The McArthur Creek volcanic rocks (Kmv) are characterized by alkali-calcic, ferroan, and peraluminous major-element compositions (figs. 7C-F). Other ferroan and peraluminous units in the region, such as granite $(\mathrm{Kg})$, granite porphyry (Kgp), and West Fork tuffs and flows (Kwff), are generally calc-alkalic. The mafic dikes $(\mathrm{Kmi})$ are calcic to calc-alkalic, magnesian, and metaluminous and are less alkalic than the alkaline dikes (Kmd, figs. 7C-E). The most calcic groups, Kgd and $\mathrm{Kgb}$, are magnesian. Unit $\mathrm{Kgd}$ is peraluminous and closely resembles the Moosehorn Range gran- 
odiorite (unit MRG; Joyce, 2002), and gabbro and diorite $(\mathrm{Kgb})$ are metaluminous and similar to the mafic dikes (Kmi, figs. 7C-E).

Trace-element compositions of the mid-Cretaceous units vary, but the correlation of some of the elements with silica suggest fractionation trends, such as plagioclase fractionation highlighted by the silica versus Sr plot (fig. 8A). Unit Kmv is characterized by bimodal Sr composition: the samples

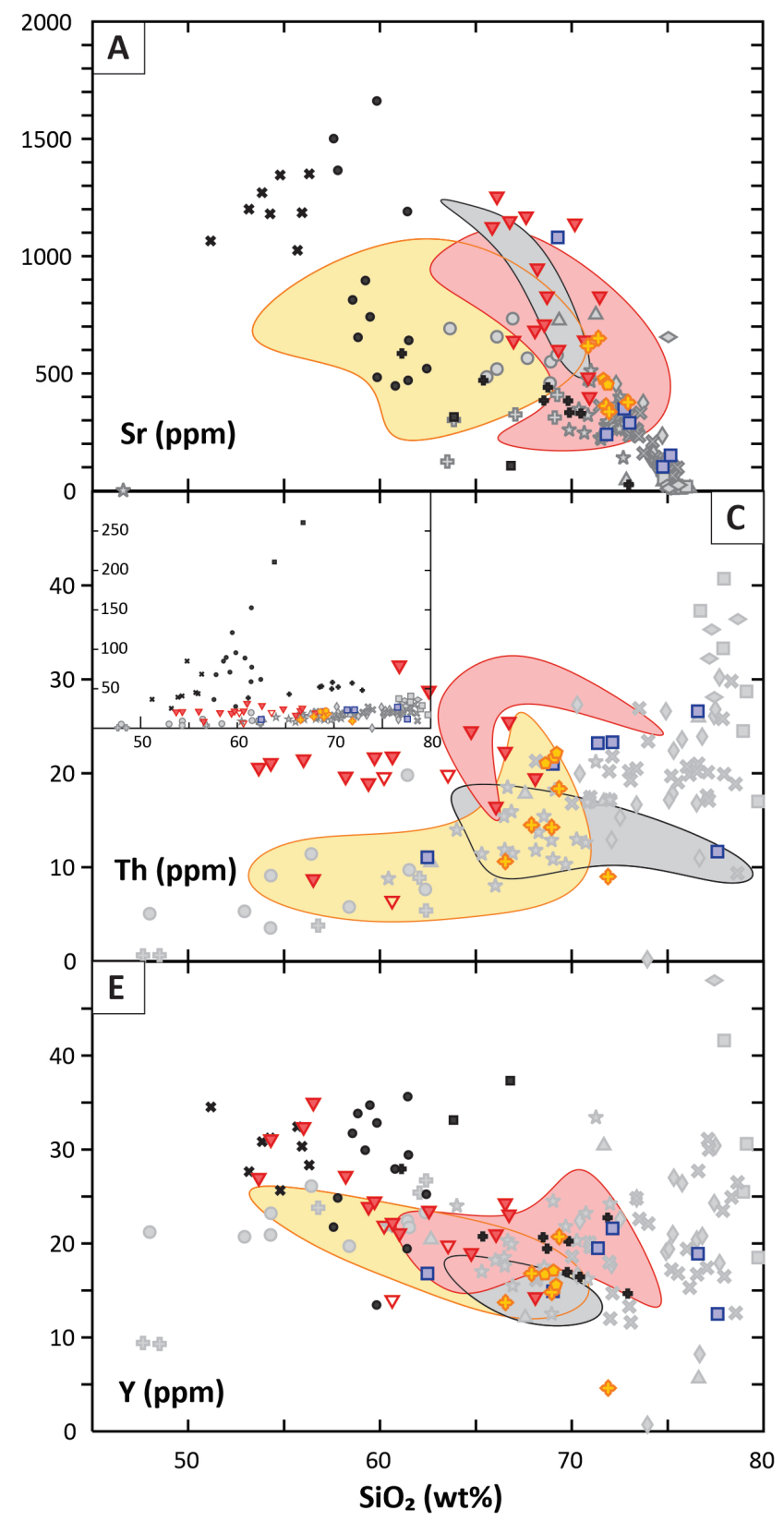

with $\mathrm{SiO}_{2}$ below 70 weight percent have higher Sr concentration-up to $750 \mathrm{ppm}$ - than other mid-Cretaceous samples, whereas the higher silica samples have a low $\mathrm{Sr}$ concentration-38 ppm (fig. $8 \mathrm{~A})$. The mafic dikes of Kmi have cohesive trace-element compositions (figs. 8A-F) comparable to other mid-Cretaceous mafic igneous rocks, but lower than the Moosehorn Range mafic dikes of Joyce (2002), highlighted by La, Eu, and Y plots

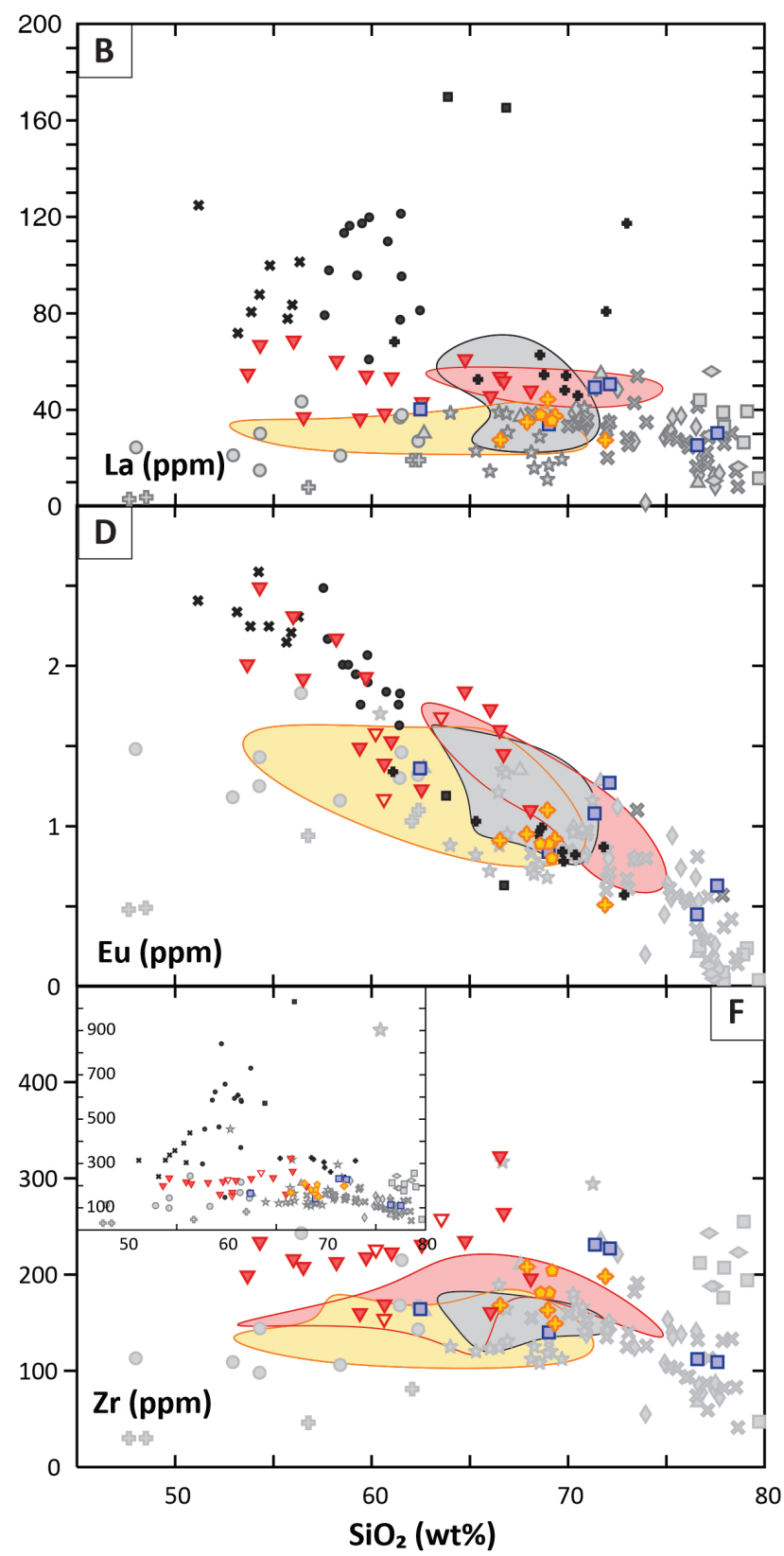

Figure 6. Bivariate plots of $\mathrm{SiO}_{2}$ (wt.\%) vs. selected trace element abundances (ppm). Symbols and colors as in figure 5; insets in $\mathrm{C}$ and $\mathrm{F}$ show an expanded $\mathrm{y}$-axis scale to accommodate Th- and Zr-rich Mount Fairplay samples. 

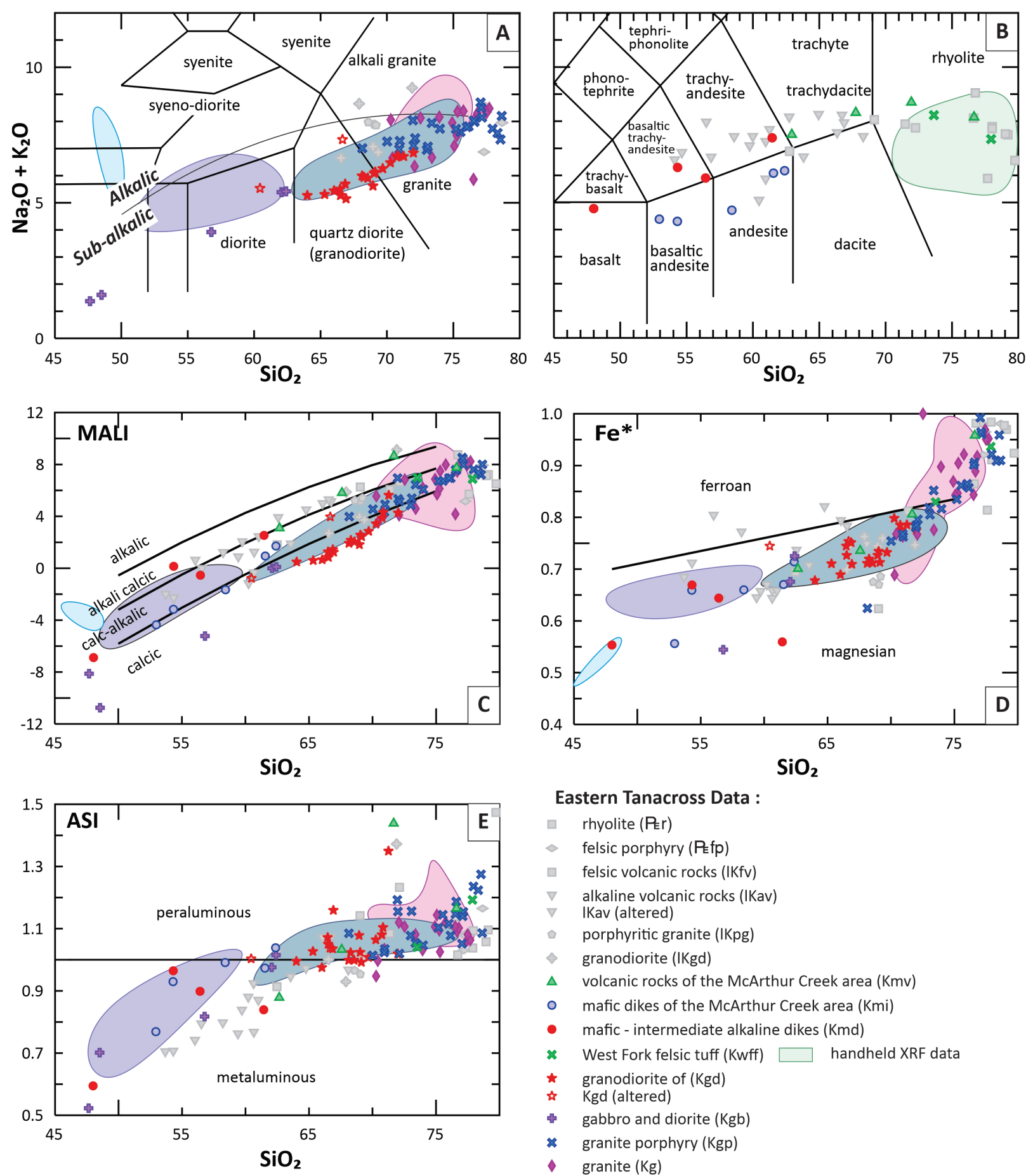

Eastern Tanacross Data :

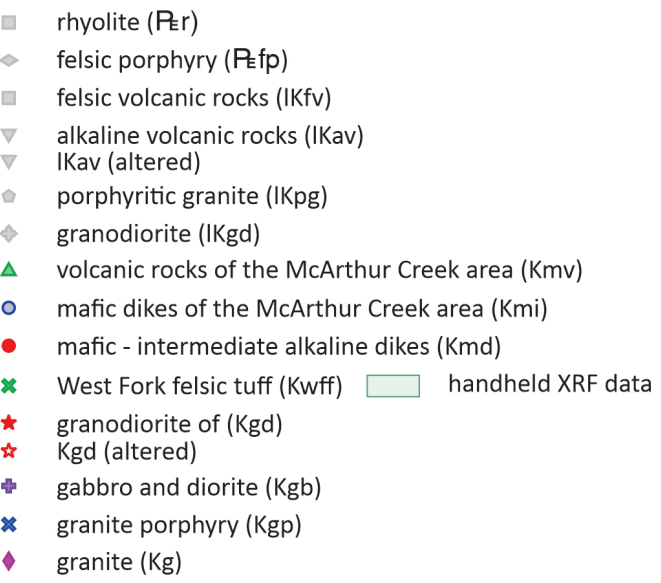

Northeast Tanacorss Data :

Moosehorn Range Data (Joyce 2002) :

granite (Kg)

Moosehorn Range granodiorite mafic dikes

lamprophyre dikes

Figure 7. Classification diagrams for mid-Cretaceous igneous rocks from the Ladue River-Mount Fairplay area. A. TAS showing the compositional range of the plutonic rocks. B. TAS showing the compositional range of the volcanic rocks and dikes. C. $\mathrm{MALI}=\mathrm{Na}_{2} \mathrm{O}+\mathrm{K}_{2} \mathrm{O}-\mathrm{CaO}$; Frost and others (2001). D. $\mathrm{Fe}^{* *}=\left(\mathrm{FeO}_{\text {tot }}\right) /\left(\mathrm{FeO}_{\text {tot }}+\mathrm{MgO}\right)$; Frost and others (2001). E. ASI $\mathrm{ASI}=\mathrm{Al} /(\mathrm{Ca}-1.67 \mathrm{P}+\mathrm{Na}+\mathrm{K})$; Frost and others (2001). Oxide data have been normalized to 100-percent anhydrous. Open symbols signify samples described (in the field by the collector) as "altered;" closed symbols represent samples described as "unaltered" or "fresh." 
(figs. 8 B,D, and E). Unit Kmd can be differentiated from the McArthur Creek mafic dikes (Kmi) by elevated $\mathrm{Sr}, \mathrm{La}, \mathrm{Th}, \mathrm{Eu}$, and $\mathrm{Zr}$ (figs. 8A-D and $\mathrm{F}$ ), and other light rare earth elements (Wypych and others, 2019). Unit Kgd is generally on trend with the MRG samples (figs. 8A-F) but differs from most of the other mid-Cretaceous igneous rocks. This is particularly well illustrated by $\mathrm{SiO}_{2}$ versus Zr plot (fig. 8F), where the granodiorite forms a separate trend. The gabbros have low trace element concentrations, except $\mathrm{Y}$ and $\mathrm{Eu}$ in a couple of more evolved, higher silica samples (figs. 8D and E). Trace element composition of $\mathrm{Kpg}$ and $\mathrm{Kg}$ are in agreement with the Kg unit of the Northeast Tanacross map area (Wypych, 2021), but separate fractionation trends on Zr plots (fig. 8F) suggest differences in zircon fractionation between the two units.

The diversity in trace-element composition in the mid-Cretaceous rocks is reflected in the tectonic classification diagrams (figs. $4 \mathrm{C}, \mathrm{D}$, and F). The majority of the units are characterized by volcanic-arc granitoid signatures, however, part of the $\mathrm{Kmv}$ group and two $\mathrm{Kg}$ samples have syn-collisional signatures; a sample from Kgb plots in the E-MORB field, and Kmd has a within-plate affinity (figs. 4C and F). In the Northeast Tanacross map area, we observed syn-collisional as well as within-plate granitoids within the Kg group (Wypych, 2021).

\section{CONCLUSIONS}

The unmetamorphosed magmatic units in the Ladue River-Mount Fairplay map area span from mid-Cretaceous to Paleogene time. Most of the Cretaceous igneous activity is volcanic-arc related (figs. 4B-D). The magnesian signature of most samples supports magma genesis under oxidized conditions (Frost and Frost, 2008). A few ferroan exceptions are the high-silica Paleogene rhyolites and porphyries ( $P_{E}, P_{E} f p$ ) and mid-Cretaceous syenite (IKsy), alkali-feldspar syenite (IKafs), and granite and granitic porphyry (Kg and Kgp units), as well as some samples from unit IKav. Late Cretaceous syenite (IKsy), alkali-feldspar syenite (IKafs,), and alkali volcanic rocks form unit IKav, as well as the Paleogene units, have distinctive "within-plate" signatures (figs. 4A and E). In mid-Cretaceous samples, this signature is observed in unit Kmd (fig. 4F), whereas siliceous samples from the McArthur Creek area have syn-collisional trace element compositions (fig. 4C). The change in geochemical signature between Cretaceous and Paleogene igneous rocks marks a change in the tectonic regime. Mid-Cretaceous extensional faulting and a ca. 115 Ma northeast-dipping subduction zone (Hansen and Dusel-Bacon, 1998; Dusel-Bacon and others, 2002, 2015) are responsible for the within-plate and volcanic-arc signatures observed in the oldest igneous rocks of eastern Tanacross (Allan and others, 2013). The Late Cretaceous magmatic pulse has a similar mixture of volcanic-arc and within-plate trace-element compositions. The Paleogene rocks display within-plate trace-element signatures almost exclusively and are highly evolved. In other parts of eastern interior Alaska, this magmatism is bimodal (Bacon and others, 1990; Foster and others, 1994; Newberry and others, 1996). The presence of alkaline Late Cretaceous rocks and Paleogene bimodal volcanism in the region suggests onset of regional extension in the Late Cretaceous and continuing into the Paleogene (Dusel-Bacon and others, 2009, 2015).

\section{ACKNOWLEDGMENTS}

The author would like to thank the DGGS Mineral Resources section field geologists and other DGGS staff who contributed to this data collection, scientific discussions, and other support.

This project was jointly funded by the State of Alaska and the U.S. Geological Survey's Earth Mapping Resources Initiative (Earth MRI) through cooperative agreement G19AC00262. The views and conclusions contained in this document are those of the authors and should not be interpreted as representing the opinions or policies of the U.S. Geological Survey. Mention of trade names or commercial products does not constitute their endorsement by the U.S. Geological Survey. 

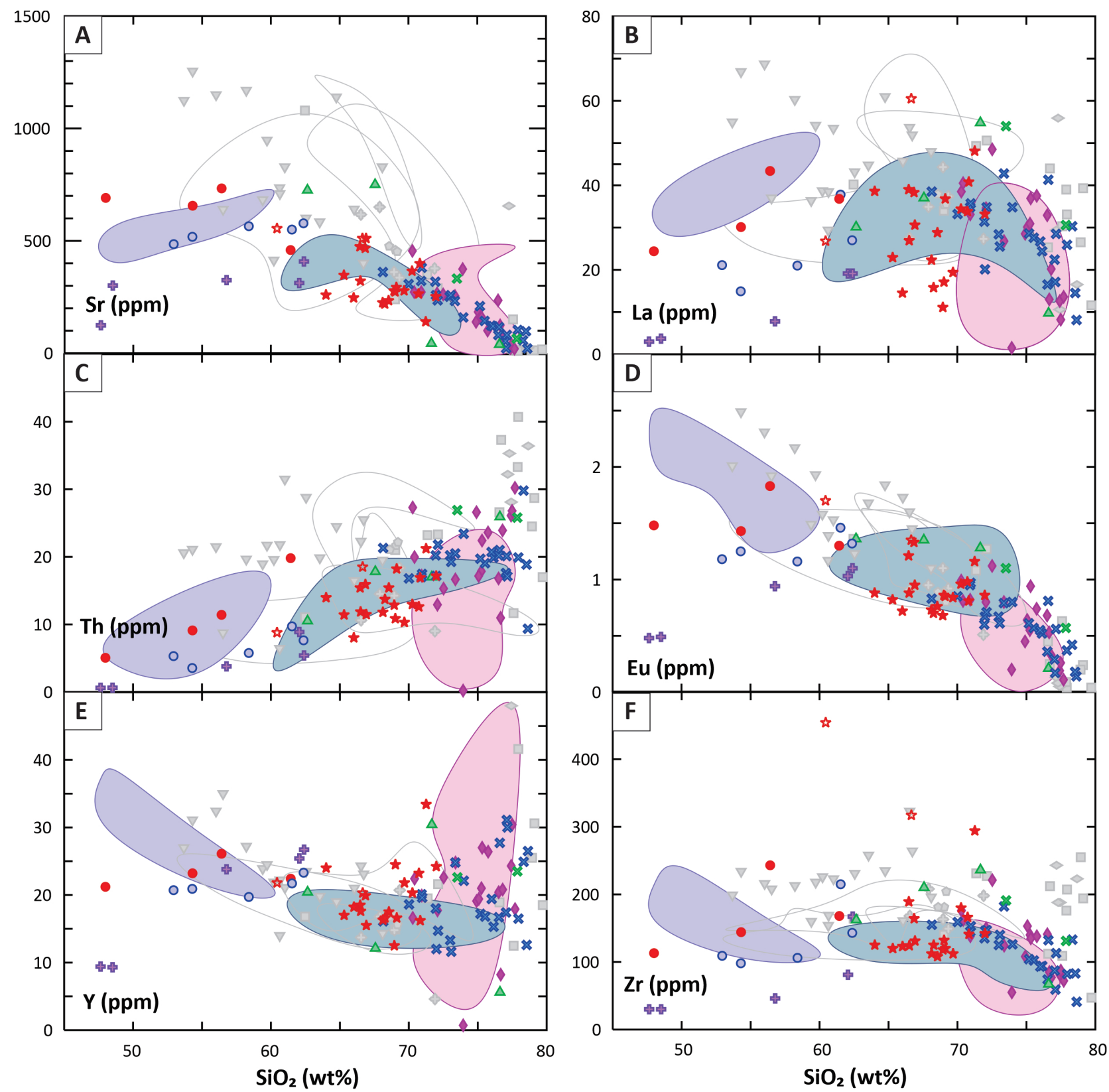

Figure 8. Bivariate plots of $\mathrm{SiO} 2$ (wt.\%) vs selected trace element abundances (ppm). Symbols and colors as in figure 7.

\section{REFERENCES}

Allan, M.M., Mortensen, J.K., Hart, C.R, Bailey, L.A., Sanchez, M.G., Ciolkiewicz, Wiltold, McKenzie, G.G., and Creaser, R.A., 2013, Magmatic and metallogenic framework of west-central Yukon and eastern Alaska, in Colpron, Maurice, Bissig, Thomas, Rusk, B.G., and Thompson,
J.F.H., Tectonics, Metallogeny, and Discovery: The North American Cordillera and Similar Accretionary Settings: Society of Economic Geologists, Special Publication 17, p. 111-168.

Bacon, C.R., Foster, H.L., and Smith, J.G., 1990, Rhyolitic calderas of the Yukon-Tanana terrane, east- central Alaska-Volcanic remnants of a midCretaceous magmatic arc: Journal of Geophysical 
Research, v. 95, no. B13, p. 21,451-21,461.

Dusel-Bacon, Cynthia, Aleinikoff, J.N., Day, W.C., and Mortensen, J.K., 2015, Mesozoic magmatism and timing of epigenetic $\mathrm{Pb}-\mathrm{Zn}-\mathrm{Ag}$ mineralization in the western Fortymile mining district, east-central Alaska: Zircon U-Pb geochronology, whole-rock geochemistry, and $\mathrm{Pb}$ isotopes: Geosphere, v. 11, no. 3, p. 786-822.

Dusel-Bacon, Cynthia, Lanphere, M.A., Sharp, W.D., Layer, P.W., and Hansen, V.L., 2002, Mesozoic thermal history and timing of structural events for the Yukon-Tanana Upland, eastcentral Alaska: ${ }^{40} \mathrm{Ar} /{ }^{39} \mathrm{Ar}$ data from metamorphic and plutonic rocks: Canadian Journal of Earth Sciences, v. 39, no. 6, p. 1,013-1,051. http://doi. org/10.1139/e02-018

Dusel-Bacon, Cynthia, Slack, J.F., Aleinikoff, J.N., and Mortensen, J.K., 2009, Mesozoic magmatism and base-metal mineralization in the Fortymile mining district, eastern Alaska-initial results of petrographic, geochemical, and isotopic studies in the Mount Veta area: Studies by the U.S. Geological Survey in Alaska, 2007: U.S. Geological Survey Professional Paper 1760-A, p. 1-42.

Foster, H.L., 1967, Geology of the Mount Fairplay area, Alaska: U.S. Geological Survey Bulletin 1241-B, p. B1-B18, 1 sheet, scale 1:63,360.

Foster, H.L., 1970, Reconnaissance geologic map of the Tanacross Quadrangle, Alaska: U.S. Geological Survey Miscellaneous Geologic Investigations Map 593, 1 sheet, scale 1:250,000.

Foster, H.L., Keith, T.E.C., and Menzie, W.D., 1994, Geology of the Yukon-Tanana area of east-central Alaska, in Plafker, George, and Berg, H.C., eds., The Geology of Alaska, v. G-1 of The Geology of North America: Boulder, Colorado, Geological Society of America, p. 205-240.

Frost, B.R., Barnes, C.G., Collins, W.J., Arculus, R.J., Ellis, D.J., and Frost, C.D., 2001, A geochemical classification for granitic rocks: Journal of Petrology, v. 42, no. 11, p. 2,033-2,048.

Frost, B.R., and Frost, C.D., 2008, A Geochemical Classification for Feldspathic Igneous Rocks: Journal of Petrology, v. 49, no. 11, p. 1,955-1,969.

Hansen, V.L., and Dusel-Bacon, Cynthia, 1998, Structural and kinematic evolution of the Yukon-Tanana Upland tectonites, east-central Alas-
ka-A record of late Paleozoic to Mesozoic crustal assembly: Geological Society of America Bulletin v. 110 , no. 2, p. 211-230.

Harrington, Edward, 2010, Technical report on the Taurus property, Fairbanks Recording District, Alaska, U.S.A.: Unpublished NI43-101 report for Senator Minerals Inc., $133 \mathrm{p}$.

Joyce, N.L., 2002, Geologic setting, nature, and structural evolution of intrusion-hosted Au-bearing quartz veins at the Longline occurrence, Moosehorn Range area, west-central Yukon Territory: Unpublished Master's thesis, University of British Columbia, Vancouver, Canada. 199 p.

Kreiner, D.C., Jones III, J.V., Todd, Erin, Holm-Denoma, Chris, Caine, J.S., Benowitz, J.A., 2019, Links between tectonics, magmatism, and mineralization in the formation of Late Cretaceous porphyry systems in the Yukon-Tanana upland, eastern Alaska, USA: Proceedings of the 15th biennial meeting for geology applied to mineral deposits, p. 939-942.

LeBas, M.J., LeMaitre, R.W., Streckeisen, Albert, and Zanettin, Bruno, 1986, A Chemical Classification of Volcanic Rocks Based on the Total Alkali-Silica Diagram: Journal of Petrology, v. 23, no. 3, p. 745-750.

Lerich, P.D., 1995, Taurus copper-molybdenum porphyry deposit, east-central Alaska, in Schroeter, T.G., ed., Porphyry Deposits of the Northwestern Cordillera of North America: Canadian Institute of Mining Metallurgy and Petroleum Special Volume 46, p. 451-457.

Meschede, Martin, 1986, A method of discrimination between different types of mid-ocean ridge basalts and continental tholeiites with the $\mathrm{Nb}-\mathrm{Zr}-\mathrm{Y}$ diagram: Chemical Geology, v. 56, p. 207-218.

Newberry, R.J., 2020, The Mount Fairplay igneous complex: Alaska Division of Geological \& Geophysical Surveys Preliminary Interpretive Report 2020-1, 32 p. https://doi.org/10.14509/30463

Newberry, R.J., Bundtzen, T.K., Clautice, K.H., Combellick, R.A., Douglas, Tom, Laird, G.M., Liss, S.A., Pinney, D.S., Reifenstuhl, R.R., and Solie, D.N., 1996, Preliminary geologic map of the Fairbanks mining district, Alaska: Alaska Division of Geological \& Geophysical Surveys Public Data File 96-16, 17 p., 2 sheets, scale 
1:63,360. https://doi.org/10.14509/1740

Pearce, J.A., Harris, N.B., and Tindle, A.G., 1984, Trace element discrimination diagrams for the tectonic interpretation of granitic rocks: Journal of Geophysical Research, v. 103, p. 7,171-7,186.

Szumigala, D.J., Newberry, R.J., Werdon, M.B., Athey, J.E., Stevens, D.S.P., Flynn, R.L., Clautice, K.H., and Craw, P.A., 2002, Geologic map of the Eagle A-1 Quadrangle, Fortymile mining district: Alaska Division of Geological \& Geophysical Surveys Preliminary Interpretive Report 2002-1A, 1 sheet, scale 1:63,360. https://doi. org/10.14509/2863

Twelker, Evan, Newberry, R.J., Wypych, Alicja, Naibert, T.J., Wildland, A.D., Sicard, K.R., Regan, S.P., Athey, J.E., Wyatt, W.C., and Lopez, J.A., 2021, Bedrock geologic map of the Ladue River-Mount Fairplay area, Tanacross and Nabesna quadrangles, Alaska, in Twelker, Evan, ed., Geologic investigation of the Ladue River-Mount Fairplay area, eastern Alaska: Alaska Division of Geological \& Geophysical Surveys Report of Investigation 2021-5A. https://doi. org/10.14509/30735

Twelker, Evan, and Newberry, R.J., 2021, Observations on the economic geology of the northeast Tanacross map area, in Wypych, Alicja, ed., Northeast Tanacross geologic mapping project, Alaska: Alaska Division of Geological \& Geophysical Surveys Report of Investigation 2020-9F. https://doi.org/10.14509/30557

Werdon, M.B., Newberry, R.J., Szumigala, D.J., and Pinney, D.S., 2001, Geologic map of the Eagle A-2 Quadrangle, Fortymile mining district, Alaska: Alaska Division of Geological \& Geophysical Surveys Preliminary Interpretive Report 2001-3A, 1 sheet, scale 1:63,360, v. 1.0.1. https://doi.org/10.14509/2669

Wilson, Marjorie, 1989, Igneous petrogenesis A Global Tectonic Approach: Unwin Hyman, London, $416 \mathrm{p}$.

Wypych, Alicja, Twelker, Evan, Naibert, T.J., Athey, J.E., Newberry, R.J., Lopez, J.A., Regan, S.P., Sicard, K.R., Wildland, A.D., and Wyatt, W.C., 2019, Major-oxide and trace-element geochemical data from rocks collected in 2019 for the Eastern Tanacross project, Tanacross and part of Nabesna quadrangles, Alaska: Alaska Division of Geological \& Geophysical Surveys Raw Data File 2019-8, 3 p. https://doi.org/10.14509/30267 Wypych, Alicja, Hubbard, T.D., Naibert, T.J., Athey, J.E., Newberry, R.J., Sicard, K.R., Twelker, Evan, Werdon, M.B., Willingham, A.L., Wyatt, W.C., and Lockett, A.C., 2021, Northeast Tanacross geologic map and map units and descriptions, in Wypych, Alicja, ed., Northeast Tanacross geologic mapping project, Alaska: Alaska Division of Geological \& Geophysical Surveys Report of Investigation 2020-9B. https://doi.org/10.14509/30539 Wypych, Alicja, 2021, Geochemical interpretation of samples of igneous rocks from northeast Tanacross, in Wypych, Alicja, Northeast Tanacross geologic mapping project, Alaska: Alaska Division of Geological \& Geophysical Surveys Report of Investigation 2020-9E. https://doi. org/10.14509/30542 